\title{
EDUKASI PENTINGNYA PRAKTIK AKUNTANSI (PENCATATAN SEDERHANA) DAN MANAJEMEN KEUANGAN DALAM RUMAH TANGGA PADA KARYAWAN RSIA PERMATA HATI MATARAM
}

\author{
Nur Fitriyah, Akram Arsyad Sukma, Alamsyah, Bambang \\ Program Studi Akuntansi \\ Jl. Majapahit No. 62 Mataram \\ nurfitriyah@unram.ac.id
}

\section{Article History:}

Received: -

Revised: -

Accepted: -

\begin{abstract}
Abstrak: Kegiatan pengabdian ini dilaksanakan pada karyawan RSIA Permata Hati Mataram karena 85\% karyawannya merupakan perempuan dengan latar belakang pendidikan kesehatan sehingga minim akan ilmu akuntansi dan manajemen keuangan dalam rumah tangga. Adapun tujuannya adalah untuk memberikan edukasi pentingnya penerapan akuntansi (pembukuan sederhana) dan manajemen keuangan dalam rumah tangga sehingga setiap keluarga dapat mengetahui kondisi keuangannya apakah dalam kondisi stabil atau lebih besar pasak dari pada tiang. Metode pelaksanaan kegiatan ini melalui pelatihan dan diskusi tentang penerapan akuntansi dalam rumah tangga dan tips dalam mengelola keuangan rumah tangga. Hasil pelaksanaan program pengabdian ini diharapkan dapat dipahami dengan baik dan dipraktikkan dalam kegiatan sehari-hari rumah tangga karyawan RSIA Permata Hati Mataram, sehingga kondisi keuangan rumah tangga terjaga dengan baik dan dapat dipertanggungjawabkan.
\end{abstract}

Kata Kunci: Akuntansi, Pembukuan Sederhana, Manajemen Keuangan, Karyawan RSIA Permata Hati Mataram 
Vol. 1, No. 1, Desember 2020

\section{PENDAHULUAN}

\section{Latar Belakang}

Perencanaan dan pengelolaan keuangan belakangan ini tidak hanya menjadi perhatian perusahaan-perusahaan yang notabenenya bergerak di bidang komersil, sekarang konsep pengelolaan keuangan pun sudah mulai dilirik oleh banyak keluarga dan rumah tangga. Banyak keluarga, terutama keluarga baru, belum mengerti bagaimana mengelola dan merencanaan keuangan rumah tangga secara baik dan benar. Hal ini dapat dilihat banyaknya keluarga yang masih merasa kekurangan dalam memenuhi kebutuhan padahal memiliki penghasilan yang cukup. Kondisi ini sebenarnya juga telah menjadi perhatian banyak akuntan, khususnya yang memiliki keahlian dalam bidang perencana keuangan, untuk membuka seminar dan pelatihan perencanaan keuangan bagi keluarga. Hal ini pun seakan menjadi sebuah peluang bisnis baru bagi akuntan publik khususnya para perencana keuangan untuk menjadi konsultan perencana keuangan pribadi.

Sejatinya, Perencanaan dan pengelolaan keuangan keluarga adalah proses merencanakan keuangan untuk mencapai tujuan-tujuan keuangan baik jangka pendek maupun jangka panjang untuk kegiatan keluarga dan rumah tangga. Perencanaan dan pengelolaan keuangan keluarga pada dasarnya adalah penerapan prinsip akuntansi pada kegiatan transaksi keuangan keluarga. Oleh karena itu, perencanaan dan pengelolaan keuangan keluarga sering disebut juga akuntansi rumah tangga. Akuntansi rumah tangga sederhananya adalah melakukan pencatatan terhadap pemasukan dan pengeluaran rumah tangga dalam periode tertentu, biasanya dilakukan secara bulanan.

Akuntansi rumah tangga adalah sesuatu yang mudah untuk dipelajari namun abai untuk diterapkan. Kesulitan penerapan bukan dikarenakan sulitnya metode dan prinsip pencatatannya, tetapi kesulitan tersebut bersumber dari keengganan keluarga untuk menerapkannya. Biasanya keluarga akan abai terhadap pencatatan pemasukan dan pengeluaran yang terjadi di rumah tangga. Mereka menganggap hal tersebut dan sepele sehingga mereka enggan melakukannya. Padahal ada banyak manfaat yang dapat didapat dengan menerapkan akuntansi rumah tangga. Salah satu contohnya dengan melakukan pencatatan atas transaksi keuangan keluarga, sebuah keluarga dapat melihat seberapa banyak manfaat yang didapat keluarga tersebut dari transaksi tersebut. 
Selain itu, keluarga pun dapat mengetahui pos-pos pengeluaran mana yang dianggap tidak perlu, sehingga kedepannya mereka dapat lebih berhemat. Apalagi di zaman modern yang serba digital dan online seperti sekarang. Transaksi belanja keluarga dilakukan dengan sangat cepat dan mudah. Hal ini dikarenakan untuk berbelanja, sebuah keluarga tidak perlu repot-repot pergi ke mall atau pusat perbelanjaan lain. Mereka hanya tinggal buka komputer, laptop atau smartphone saja untuk berbelanja. Pembayarannya pun dilakukan dengan instan yaitu melalui internet banking atau kartu kredit. Hal ini tentunya tidak jarang membuat sebuah keluarga kalap dalam berbelanja dan tanpa sadar menghabiskan banyak uangnya. Dengan menerapkan akuntansi, minimal pencatatan sederhana untuk penerimaan dan pengeluaran, maka dapat membantu anggota keluarga mengetahui sistem keuangan keluarga, apakah stabil ataukah lebih besar pasak daripada tiang. Laporan Akuntansi keluarga ini menjadi fondasi penting dalam proses perencanaan keuangan sehingga wajib dibuat dan diperbarui, minimal sekali dalam satu tahun. Jika melihat kondisi di atas, boleh dikatakan bahwa akuntansi dan manajemen keuangan dalam rumah tangga sangat diperlukan oleh setiap keluarga.

Adapun alasan pemilihan objek dan lokasi pengabdian pada karyawan RSIA Permata Hati Mataram karena sebagian besar karyawannya (85\%) merupakan perempuan dengan latar belakang pendidikan yang beragam dan sebagian besar dari pendidikan kesehatan sehingga minim akan ilmu akuntansi dan manajemen keuangan dalam rumah tangga.

\section{Tujuan}

\section{Tujuan Umum}

Memberikan edukasi pentingnya penerapan akuntansi (pembukuan sederhana) dan manajemen keuangan dalam rumah tangga.

\section{Tujuan Khusus}

1. Meningkatkan pemahaman karyawan RSIA Permata Hati dalam bidang akuntansi dan manajemen keuangan rumah tangga.

2. Meningkatkan kesadaran dan pengetahuan ibu rumah tangga akan pentingnya informasi yang diperoleh untuk diri sendiri dan anggota keluarga lainnya. 
Vol. 1, No. 1, Desember 2020

3. Setiap anggota keluarga dapat mengetahui kondisi keuangan keluarga, sehingga dapat mengambil keputusan keuangan dan dampaknya bagi rumah tangga.

4. Menjadi agen penyebar informasi tentang pentingnya akuntansi dan manajemen keuangan rumah tangga bagi keluarga lain di lingkungan sekitar.

\section{METODE KEGIATAN}

Metode kegiatan yang digunakan yaitu pendidikan disusun berdasarkan analisis kebutuhan ibu rumah tangga sebagai manajer keuangan dalam keluarga masing-masing. Pendidikan diberikan dalam bentuk penyuluhan dan diskusi mengenai pencatatan sederhana dan manajemen keuangan rumah tangga. Kegiatan dilaksanakan pada karyawan RSIA Permata Hati Mataram yang berlokasi di Jl. Majapahit No. 10C Kelurahan Kekalik Jaya Kecamatan Sekarbela Kota Mataram.

Sebagian besar karyawan RSIA Permata Hati merupakan perempuan yang notabenenya jika di rumah sebagai ibu rumah tangga. Selain itu profesinya yang sebagai tenaga medis, umumnya minim akan ilmu akuntansi dan manajemen, khusunya dalam rumah tangga. Dengan adanya edukasi ini diharapkan karyawan yang juga sebagai ibu rumah tangga dapat lebih sadar akan pentingnya penerapan akuntansi dan manajemen keuangan dalam rumah tangga sehingga dapat mengetahui kondisi keuangan keluarga dapat menyebarkan informasi tersebut kepada kelompok ibu rumah tangga di lingkungan lainnya.

Prosedur yang digunakan oleh tim pengabdian adalah sebagai berikut:

\section{Memberikan pemahaman dasar tentang akuntansi dan manajemen keuangan dengan metode ceramah.}

\section{Arti Pembukuan}

Pembukuan ini dapat diartikan secara harfiah yaitu sebagai pencatatan transaksi keuangan oleh perorangan atau organisasi yang meliputi penjualan, pembelian, pendapatan dan pengeluaran. Pembukuan adalah pencatatan yang teratur mengenai jumlah uang atau barang yang diterima dan yang dikeluarkan. Pembukuan juga dapat diartikan sebagai pencatatan terhadap pengeluaran dan 
penerimaan uang atau barang sangat penting dilakukan dalam kegiatan usaha.

\section{Manfaat Pembukuan}

Begitu pentingnya manfaat dari pembukuan ini, namun jarang sekali pengusaha atau individu yang melaksanakan pembukuan ini. Adapun manfaat dari pembukuan ini dapat dirinci sebagai berikut:

- Dapat diketahui jumlah uang atau barang yang diterima

- Dapat diketahui jumlah uang atau barang yang dikeluarkan

- Dapat diketahui mengenai jenis-jenis penerimaan dan pengeluaran

- $\quad$ Dapat diketahui sisa uang atau barang

- Dapat diketahui kondisi keuangan

\section{Sistem Manajemen Keuangan Rumah Tangga}

Cara mencatat dan mengelola keuangan dengan baik, kita susun dulu kebutuhan - kebutuhan yang emang sudah biasa dibayarkan setiap bulan dari pendapatan bulanan seperti bayar listrik, telepon, bensin dan ada beberapa kebutuhan yang memang harus diperhatikan juga. kebutuhan untuk hari tua, atau kebutuhan untuk nanti ketika kita tidak bisa lagi bekerja, sementara kebutuhan hidup harus tetap terpenuhi. beberapa tips sederhana mengelola keuangan rumah tangga. Menerapkan sistem 123 dan 4. Sistem yang sangat mudah diingat oleh siapapun juga, dan sistem ini pun akurat.

1. Yang harus dilakukan pertama adalah dengan angka 1 . Angka 1 ini sebenarnya kependekan dari 10\%. Jadi supaya lebih gampang diingat ya disingkat aja, hehe. Biasanya saya sisihkan $10 \%$ dari pendapatan bulanan saya dan suami dan pendapatan lainnya untuk kebutuhan saya nanti dihari tua. Tabungan ini boleh diambil ketika nanti saya benar - benar membutuhkannya.

2. Kemudian langkah selanjutnya adalah angka 2, yakni $20 \%$.Dalam angka $20 \%$ ini saya sisihkan untuk biaya listrik,bensin, pulsa handphone dan kebutuhan rumah tangga.

3. Dan angka $30 \%$ dari pendapatan saya alokasikan untuk biaya pendidikan anak, cicilan - cicilan dan asuransi pendidikan.

Sisanya $40 \%$ dari pendapatan bulanan saya ini saya sebut uang dingin. Jadi uang dingin ini saya biasanya suka belanjakan untuk beli baju, sepatu atau bahkan untuk sekedar makan diluar bersama keluarga. Dan 
Vol. 1, No. 1, Desember 2020

biasanya setiap akhir bulan suka ada sisa lho dari uang dingin ini dan sisanya saya masukkan saja ke tabungan.

\section{Memberikan ilustrasi cara pencatatan akuntansi sederhana} Contoh Buku Kas sederhana

Tabel 1. Buku Kas Bulan Desember 2019

\begin{tabular}{|c|c|c|c|c|c|}
\hline No & Tgl & Uraian & Penerimaan & Pengeluaran & Sisa \\
\hline & & Saldo kas bulan & & & $\mathrm{Rp}$ \\
\hline 1 & Des 1 & lalu & & & 350.000 \\
\hline 2 & Des 1 & Menerima gaji & Rp3.500.000 & & Rp.3.850.000 \\
\hline & & Belanja & & & $\mathrm{Rp}$ \\
\hline 3 & Des 2 & mingguan & & Rp 250,000 & 3.600 .000 \\
\hline & & & & & $\mathrm{Rp}$ \\
\hline 4 & Des 5 & Bayar listrik & & Rp 200,000 & $3.400,000$ \\
\hline & Des & Bayar Air dan & & & $\mathrm{Rp}$ \\
\hline 5 & 10 & Telp & & Rp 300,000 & $3.100,000$ \\
\hline 6 & Des & Bayar cicilan & & $\mathrm{Rp}$ & Dn16 6000 \\
\hline
\end{tabular}

\section{Memberikan tips dalam mengelola dan mencatat keuangan rumah tangga}

Ada beberapa tips agar anda bisa secara konsisten menulis setiap perubahan kas yang terjadi di dalam rumah tangga. Beberapa diantaranya:

1. WAJIB meminta kuitansi. Kumpulkan segala struk belanja ketika kita mengeluarkan kas. Simpan di dompet atau tas penting tidak lupa dan mudah kita buka ketika kita memerlukannya. 


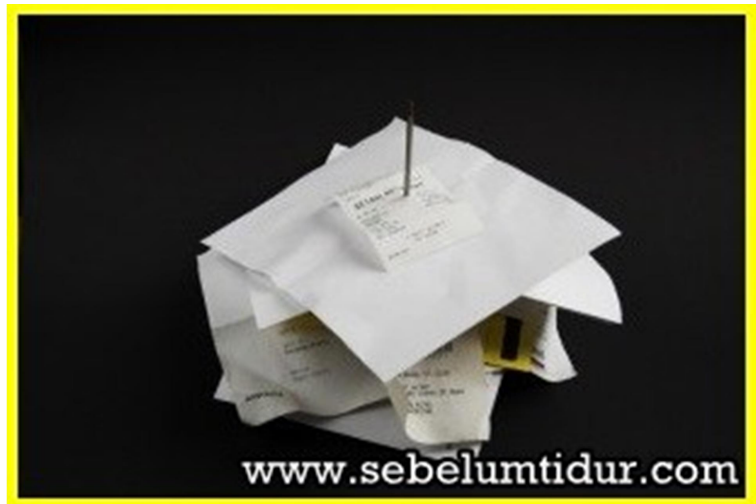

Gambar 1. Kumpulan Struk Belanja

2. CATAT segera selepas mengeluarkan kas Setiap hari. Jika bepergian dan berada di luar rumah dalam waktu yang relative lama, maka dapat dicatat dulu di HP. Misal simpan di pesan / sms atau kalau sudah pake smartphone jauh lebih mudah, simpan aja di kalender yang ada di smarphone itu.

3. Desainlah buku catatan keuangan sesimpel mungkin. Jika tidak ingin repot, maka buku kas dapat dibeli karena banyak tersedia di toko-toko alat tulis (stationary)

4. Kerjasama dengan pasangan agar saling mau mencatat pengeluaran / pemasukannya. Ini sekaligus melatih akuntabilitas satu sama lain. Kadang suami misal kasih istri uang berapa kok sudah habis, dia protes. Padahal dari data yang banyak pakai uang itu malah suami sendiri. Ada buku catatan kas beserta notanya akan menjadi senjata pertahanan bagi ibu.

5. TIDAK PERLU mempergunakan aneka aplikasi yang ada di IOS / Android. Berlatih mencatat manual jauh lebih baik sekaligus melatih bawah sadar kita terbiasa tertib dan terakuntansi dengan baik

6. Apabila ingin menabung, tabunglah di awal saat ada pemasukan kas dari gaji. Tabung dengan uang pertama, bukan uang sisa. 
Vol. 1, No. 1, Desember 2020

4. Memberikan ilustrasi laporan keuangan rumah tangga

Tabel 2. Contoh Laporan Posisi Keuangan (Neraca)

\begin{tabular}{l|l}
\hline \multicolumn{2}{c}{$\begin{array}{c}\text { RUMAH TANGGA BAPAK BUDI } \\
\text { PER 31 DESEMBER 2019 (DALAM RIBUAN) }\end{array}$} \\
\hline \multicolumn{1}{c}{ ASET } & \multicolumn{1}{c}{ LIABILITAS \& EKUITAS } \\
\hline Kas & Utang listrik \\
Rp10.000 & Rp 750 \\
\hline Surat Berharga & Utang Air \\
5.000 & Rp 250 \\
\hline Piutang & Utang Telepon \\
Rp50.000 & 250 \\
\hline $\begin{array}{l}\text { Perlengkapan } \\
\text { Rp 5.000 }\end{array}$ & Kartu Kredit \\
\hline Jumlah Aset Lancar & 2.000 \\
Rp70.000 & Jumlah Utang Lancar \\
\hline Tanah & $\mathbf{3 . 2 5 0}$ \\
Rp100.000 & Utang Bank (KPR) \\
\hline Bangunan & Rp200.000 \\
Rp150.000 & Utang Bank (Mikro) \\
\hline Kendaraan & Rp50.000 \\
\hline 50.000 & Jumlah Utang Jk. Panjang \\
\hline Peralatan & Rp250.000 \\
\hline J.000 & Modal \\
\hline Jumlah Aset Tetap & Rp140.750 \\
\hline Rp325.000 & Laba(Sisa Bulanan) \\
\hline Total Aset & 1.000 \\
\hline Rp395.000 & Total Liabilitas \& Ekuitas \\
\hline & Rp395.000 \\
\hline
\end{tabular}


Tabel 3. Contoh Laporan Laba Rugi (Sisa Hasil Usaha)

\begin{tabular}{|l|r|}
\hline \multicolumn{2}{|c|}{$\begin{array}{c}\text { RUMAH TANGGA BAPAK BUDI } \\
\text { LAPORAN LABA RUGI }\end{array}$} \\
\hline \multicolumn{2}{|c|}{ PERIODE 1 DESEMBER - 31 DESEMBER 2019 (DALAM RIBUAN) } \\
\hline Pendapatan: & JUMLAH \\
\hline Gaji Bapak & Rp10.000 \\
\hline Gaji Ibu & Rp15.000 \\
\hline Jumlah Pendapatan & Rp7.500 \\
\hline Beban-Beban: & Rp3.000 \\
\hline Belanja Bulanan & Rp500 \\
\hline Belanja Harian & Rp750 \\
\hline Beban listrik & Rp1.250 \\
\hline Beban Air & Rp14.000 \\
\hline Beban Telepon & Rp1.000 \\
\hline Beban Bunga Bank & \\
\hline Jumlah Beban &
\end{tabular}

Kegiatan akuntansi dalam rumahtangga sangat diperlukan untuk tracking kemana larinya uang gaji/ hasil usaha selama ini. Juga dapat membantu mengetahui sistem keuangan keluarga anda apakah stabil ataukah lebih besar pasak daripada tiang. Laporan Akuntansi keluarga ini menjadi fondasi penting dalam proses perencanaan keuangan sehingga wajib dibuat dan diperbarui, minimal sekali dalam satu tahun.

\section{Menjelaskan tahapan akuntansi untuk menyusun laporan keuangan rumah tangga}

Di bawah ini merupakan tahapan untuk meng"akuntansikan" keuangan keluarga.

1. Laporan kekayaan bersih

Laporan kekayaan bersih terdiri dari jenis aset dan kewajiban yang dimiliki oleh seorang individu. Untuk sisi aset, pisahkan aset kedalam kategori

a. aset lancar contohnya uang cash, deposito, emas, piutang, perlengkapan.

b. aset tidak lancar contohnya mesin, kendaraan, tanah dan rumah

c. dan aset investasi. 
Vol. 1, No. 1, Desember 2020

Sementara untuk sisi kewajiban, kelompokkan menjadi

a. kewajiban lancar contohnya hutang leasing kendaraan bermotor

b. dan kewajiban tidak lancar contohnya pembayaran asuransi tahunan

buat tabel asset dan kewajiban, isi nilai di Tabel Kekayaan Bersih dengan nilai wajar jika dijual saat ini. Sebagai contoh, Anda memiliki sebuah mobil avanza tahun 2010 dengan harga 142 juta. Dalam laporan kekayaan bersih tahun 2015, tentu nilai mobil Anda bukan lagi 142 juta, tapi kurang dari nilai tersebut, misal 100 juta karena adanya penurunan fungsi mobil akibat penggunaan/ penyusutan. Masukkan angkanya kedalam asset tidak lancar.

Setelah itu, kurangkan jumlah aset terhadap jumlah kewajiban. Selisih keduanya merupakan nilai kekayaan bersih Anda. Periksalah hasilnya positif atau negatif?

2. Laporan arus kas

Laporan arus kas terdiri dari jenis pemasukan dan pengeluaran beserta nilainya.

a. Arus kas bulanan, jenis pemasukan dan pengeluaran yang dihitung bersifat tetap/ hampir selalu ada setiap bulannya.

- pemasukan rutin yang bersifat tetap adalah gaji bulanan.

- pengeluaran rutin, Tagihan telepon dan listrik, belanja bulanan, uang SPP bulanan anak, dan tagihan rutin bulanan lainnya.

b. Arus kas tahunan, jenis pemasukan dan pengeluaran bersifat tidak rutin.

- pemasukan tidak rutin: Bonus/ THR

- pengeluaran tidak rutin : dana liburan/ dana pulang kampung

Idealnya, pendapatan rutin digunakan untuk membiayai pengeluaran rutin dan pendapatan tidak rutin digunakan untuk membiayai pengeluaran tidak rutin, sehingga tidak terjadi mismatch. Apabila jumlah pengeluaran tidak melebihi jumlah pendapatan, maka Anda punya sisa arus kas positif yang bisa digunakan untuk berbagai keperluan, seperti

1. melunasi utang,

2. menambah dana darurat (minimal nilainya adalah 6 bulan gaji)yang belum mencapai jumlah yang ideal,

3. meningkatkan porsi tabungan dan investasi 
semua tergantung dari kondisi keuangan Anda, jika ternyata jumlah pengeluaran lebih besar daripada jumlah pendapatan, segera mengevaluasi pos-pos anggaran mana yang bocor/salah kelola.

\section{HASIL DAN PEMBAHASAN}

Di bawah ini faktor-faktor pendorong dan penghambat pelaksanaan pelatihan dan pendampingan, yaitu:

\section{Faktor Pendorong}

1. Terjalinnya kerjasama yang baik antara tim pengabdian dengan manajemen dan karyawan RSIA Permata Hati Mataram.

2. Selama pelaksanaan kegiatan pelatihan akuntansi pencatatan sederhana dan manajemen keuangan, karyawan RSIA Permata Hati Mataram memberikan apresiasi yang baik. Peserta secara aktif mengikuti kegiatan pelatihan dari awal hingga akhir, hal ini ditunjukkan dengan banyaknya pertanyaan dan saran baik dari manajemen maupun dari karyawan RSIA Permata Hati Mataram. Berikut gambaran suasana pada saat kegiatan dilakukan.

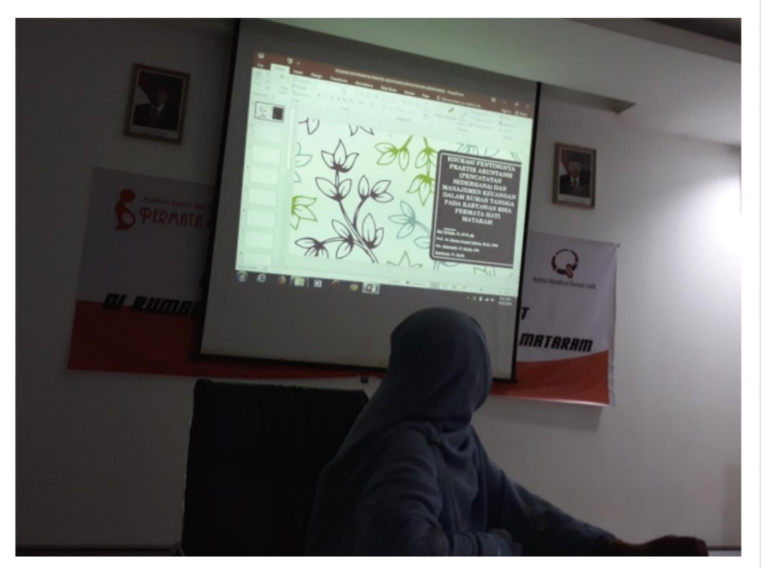

Gambar 2. Pemaparan materi oleh tim pengabdian 


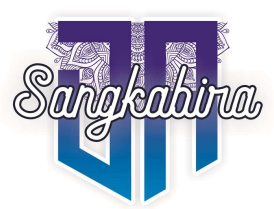

Vol. 1, No. 1, Desember 2020

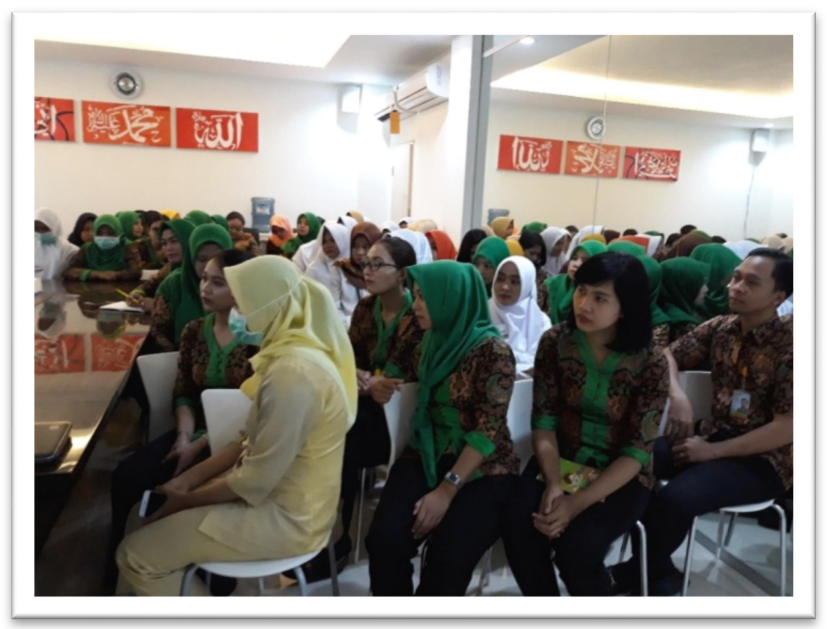

Gambar 3. Peserta mendengarkan pemaparan materi oleh tim pengabdian

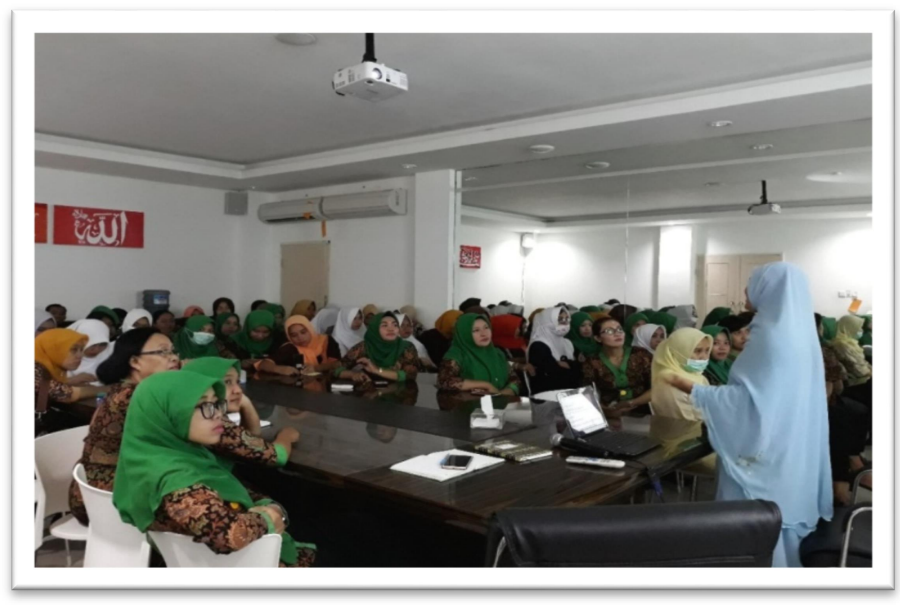

Gambar 4. Sesi Diskusi dan Tanya Jawab

\section{Faktor Penghambat}

Sulitnya menyatukan jadwal antara karyawan RSIA Permata Hati Mataram dengan tim pengabdian kepada masyarakat. Yang mana jam kerja karyawan berdasarkan 3 shift yaitu pagi, siang, dan malam. Sehingga kegiatan ini dilaksanakan dalam 2 shift yaitu pagi dan siang. Namun, secara keseluruhan tidak ada hambatan yang terlalu teknis maupun administratif. 


\section{KESIMPULAN DAN SARAN}

\section{Kesimpulan}

Melalui pelatihan praktik akuntansi pencatatan sederhana dan manajemen keuangan rumah tangga pada karyawan RSIA Permata Hati Mataram, karyawan akhirnya dapat memahami dan diharapkan dapat mempraktikan pencatatan akuntansi sederhana atas setiap transaksi yang terjadi dalam rumah tangga dan melakukan pengelolaan terhadap pengeluaran yang disesuaikan dengan penerimaan yang diperoleh, sehingga kondisi keuangan rumah tangga terjaga dengan baik dan dapat dipertanggungjawabkan.

\section{Saran}

Mengingat kegiatan ini hanya diadakan di satu entitas saja, harapannya entitas yang lain juga mendapatkan kesempatan yang sama untuk mengikuti pelatihan. Alternative lain dapat melanjutkan kegiatan pelatihan dan pendampingan dengan dengan tema yang berbeda dan dengan dana yang lebih besar.

\section{UCAPAN TERIMA KASIH}

Tim pengabdian kepada masyarakat mengucapkan terima kasih kepada Fakultas Ekonomi dan Bisnis Universitas Mataram yang telah mendanai kegiatan ini melalui dana PNBP dan kepada Manajemen RSIA Permata Hati Mataram yang telah memberikan izin dan fasilitas ruangan/aula sebagai tempat pelaksaan kegiatan. Tidak lupa tim pengabdian mengucapkan terima kasih kepada seluruh karyawan RSIA Permata Hati Mataram yang telah meluangkan waktunya untuk mengikuti kegiatan ini dari awal sampai akhir secara antusias.

\section{DAFTAR PUSTAKA}

Munawir, S. 2001. Analisa laporan Keuangan.Yogyakarta: Liberty

Ary. 2015. Akuntansi Dalam Rumah Tangga akuntansi-dalam-rumah-tangga.html Lusiana, Tian. 2015. Akuntansikan Keuangan Rumah Tangga

http://www.sebelumtidur.com

https://www.akuntansionline.id 